\title{
Effect of nitrogen and sulphur nutrition on storage protein quality in soybean [Glycine max (L.) Merrill]
}

\author{
A. Sharma* and S. Sharma \\ Department of Biochemistry, Punjab Agricultural University, Ludhiana-141004 (Punjab), INDIA \\ *Corresponding author. E-mail: anju3sep@gmail.com \\ Received: December 12, 2014; Revised received: October 3, 2017; Accepted: February 5, 2018
}

\begin{abstract}
The relative availabilities of nitrogen and sulphur can modulate seed storage protein composition in grain legumes and cereals. Soybean contains two major seed storage proteins, glycinins and $\beta$-conglycinins that account for approximately $70 \%$ of total protein and their composition is affected by nitrogen and sulphur supplies. The present study demonstrated the effect of sulphur (Gypsum @ $20 \mathrm{~kg} \mathrm{~S} \mathrm{ha}^{-1}$ ) and recommended a dose of nitrogen (Urea @ $31.25 \mathrm{~kg} \mathrm{~N} \mathrm{ha}^{-1}$ ) alone or in combination on accumulation patterns of various protein fractions and protein quality in soybean seeds under agro-climatic conditions of Punjab. Application of nitrogen or sulphur alone decreased the relative proportion of $\beta$-subunit of purified $\beta$-conglycinin fraction than control. The acidic polypeptides of glycinin fraction of globulin and 11S/7S ratio were increased in all the treatments in comparison to control, and the maximum increase was reported in the combined application of gypsum with the recommended dose of urea. The lower proportion of total 7S, increased acidic polypeptides and improved 11S:7S ratio by combined treatment of nitrogen and sulphur suggests that gypsum @ $20 \mathrm{~kg} \mathrm{~S} \mathrm{ha}^{-1}$ can be beneficial when applied along the recommended nitrogen dose to improve soybean protein quality.
\end{abstract}

Keywords: Nitrogen, Protein quality, Soybean, Sulphur

\section{INTRODUCTION}

Soybean (Glycine max (L.) Merrill), an important leguminous crop, is grown worldwide as it contains high edible protein and vegetable oil (Arslanoglu et al., 2011). The two major storage proteins in soybeans are glycinin and $\beta$-conglycinin that account for $40 \%$ and $25 \%$ of the total seed proteins, respectively. $\beta$ conglycinin, a glycoprotein $(\mathrm{Mr} \sim 150-175 \mathrm{kDa})$ is composed of three non-identical subunits: $\alpha, \alpha^{\prime}, \beta$ with a molecular weight (Mr) of 76, 72, and $53 \mathrm{kDa}$, respectively and contains no disulfide bonds (Thanh and Shibasaki, 1978). Glycinin, a hexameric protein $(\mathrm{Mr} \sim 320$ $-380 \mathrm{kDa})$ is composed mainly of subunits A3; total A1a, A1b, A2, A4 and acidic and total basic subunits with molecular weight 45,38 and $22 \mathrm{kDa}$, respectively (Beilinson et al., 2002). Each glycinin monomer consists of a specific acidic polypeptide chain linked by a disulphide bond to a specific basic polypeptide chain on the basis of the identity of their amino acid composition (Adachi et al., 2003). The mean glycinin to $\beta$ conglycinin ratio varies from 1.6 to 2.5 among soybean varieties (Fehr et al., 2003). This ratio influences the protein quality and affects the functional properties of food products made from soybeans (Poysa et al., 2006). The sulphur amino acid content of storage protein glycinin and conglycinin varies from 3-4.5\% and less than $1 \%$, respectively (Yaklich, 2001).
Although soybean is grown over a small area in Punjab state but due to its high nutritional value and low water requirements as compared to rice, it can be exploited as an alternative to rice in rice-wheat cropping cycle. Tea et al. (2007) have reported that large amounts of nitrogen $(\mathrm{N})$ fertilizers are applied to crops without considering the sulphur $(\mathrm{S})$ requirements which are of great concern for improving crop quality. In our earlier work, we have studied the effect of various sources and levels of sulphur fertilizers on storage protein accumulation in soybean crop to find out the optimum levels of sulphur under the agro-climatic conditions of Punjab and observed that gypsum@20 kg ha ${ }^{-1}$ showed maximum seed storage proteins accumulation in soybean. $\mathrm{S}$ and $\mathrm{N}$ assimilation pathways are well coordinated in plants (Kopriva and Rennerberg, 2004; Siddiqui et al., 2008) and there is a regulatory interaction between the assimilation of these two nutrients. Thus, the present study was undertaken to assess the effect of sulphur (gypsum @20 kg S ha ${ }^{-1}$ ) along with recommended dose of nitrogen (urea@31.25 kg N ha-1) either alone or in combination on soybean storage protein quality and subunit composition.

\section{MATERIALS AND METHODS}

A field experiment was conducted at experimental fields of Pulses Section, Department of Plant Breeding 
and Genetics, PAU, Ludhiana during kharif season (2013) on soybean cultivar SL 525. The experiment was laid out with four replications in a randomized block design with four treatments i.e. control (T1), urea@31.25 kg N ha ${ }^{-1}$ (T2), gypsum@20 kg S ha ${ }^{-1}$ (T3) and urea@31.25 kg N ha ${ }^{-1}+$ gypsum@20 kg S $\mathrm{ha}^{-1}$ (T4). The experimental soil was sandy loam in texture having $\mathrm{pH} 7.7$, electrical conductivity 0.15 mmoles $\mathrm{cm}^{-1}$, organic carbon $0.51 \%$ and available nitrogen, phosphorus, potassium and sulphur contents were $0.26 \%, 14.3 \mathrm{~kg}$ acre $^{-1}, 30 \mathrm{~kg}$ acre $^{-1}$ and $0.22 \%$ respectively. Seeds were collected at maturity from each treatment. For extraction of total proteins, seed powder $(1 \mathrm{~g})$ was defatted with $5 \mathrm{ml}$ mixture of chloroform, methanol and acetone $(2: 1: 1)$ for $3 \mathrm{hrs}$, the solution was decanted, and seed powder was dried by leaving the vials open at room temperature overnight. To each vial, $5 \mathrm{ml}$ of Tris-HCl buffer was added to extract soluble proteins and samples were kept overnight at $10^{\circ} \mathrm{C}$. The samples were centrifuged at $10,000 \mathrm{rpm}$ for $10 \mathrm{~min}$ and supernatant thus obtained was used for electrophoresis (Varier and Dadlani, 1992). Glycinins and $\beta$-conglycinins were extracted from defatted soybean flour with 5-6 volumes of $0.1 \mathrm{M}$ potassium phosphate buffer ( $\mathrm{pH}$ 7.0) and further isolated by repeated isoelectric precipitations (Basha and Beevers, 1975) where glycinins were recovered at $\mathrm{pH} 6.4$ while $\beta$ conglycinins were obtained at $\mathrm{pH}$ 4.8. The protein content was determined in all the samples by the method of Lowry et al. (1951).

The protein extract $(200 \mu \mathrm{g})$ was mixed with equal volume of sample buffer containing Tris- $\mathrm{HCl}(\mathrm{pH} \mathrm{6.8),} \mathrm{10 \%}$ sucrose, SDS, mercaptoethanol and 1\% bromophenol blue and placed for $3 \mathrm{~min}$ in a boiling water bath. After cooling to room temperature, the processed sample was heated at $90^{\circ} \mathrm{C}$ for $2-3 \mathrm{~min}$ in boiling water bath to ensure complete dissociation of protein subunits and optimum SDS binding. Electrophoresis (SDS-PAGE) was carried out according to the standard procedure (Laemmli, 1970) in $1.5 \mathrm{~mm}$ thick gels with $12.5 \%$ (w/ v) separating gel and 5\% (w/v) stacking gel in a vertical electrophoresis unit. In one of the outside wells of each gel, molecular weight markers ranging from 14.3 to $97.4 \mathrm{kDa}$ (Bangalore Genei Pvt. Ltd., Bangalore, India) were run to determine the molecular weight ranges of polypeptides and to identify the subunits of the major soybean proteins. Hundred $\mu \mathrm{g}$ of each sample was loaded on the gel and electrophoresis was carried out at a constant current of $1.5 \mathrm{~mA}$ per well at room temperature until dye reached near the bottom of the slab gel. The resolved proteins were prefixed by keeping the gels for $1 \mathrm{~h}$ in TCA (12.5\%) followed by overnight staining in $0.1 \%$ Coomassie Brilliant Blue G -250 (Sisco Research Laboratories Pvt. Ltd.) in methanol: acetic acid: distilled water (50:10:40, v/v/v) and destaining in mixture of methanol: acetic acid: water $(10: 7: 83, \mathrm{v} / \mathrm{v} / \mathrm{v})$. The molecular weight of specific protein bands in the gel was calculated from their mobility from the wells and extrapolating from the standard curve plotted from the mobility of marker proteins against their log molecular weights. Quantitative assessment of relative protein content was made by computer-assisted densitometry using the Quantity-one Software (BioRad), and protein was reported in relative amounts per gel.

Statistical analysis: The data were analysed for the critical differences between treatments by applying one -way analysis of variance (ANOVA) at $\mathrm{P} \leq 0.05$ using CPCS1 software package.

\section{RESULTS AND DISCUSSION}

To study the influence of $\mathrm{N}$ and $\mathrm{S}$ alone or in combination with banding patterns of subunits of soybean storage proteins, total proteins were extracted and subjected to SDS-polyacrylamide electrophoresis. The banding patterns of different subunits of glycinin and $\beta$ -

Table 1. Effect of nitrogen and sulphur fertilization on SDS-PAGE analysis of total seed proteins in soybean seeds.

\begin{tabular}{|c|c|c|c|c|c|c|c|c|c|}
\hline Treatment & Lox & $\alpha^{\prime}$ & $\mathbf{A}$ & B & $\begin{array}{l}\text { Total } \\
7 \mathrm{~S} \\
\end{array}$ & Acidic & Basic & $\begin{array}{l}\text { Total } \\
11 S \\
\end{array}$ & $\begin{array}{l}\text { 11S:7S } \\
\text { Ratio }\end{array}$ \\
\hline Control & 13.87 & 10.82 & 6.09 & 2.18 & 19.10 & 7.28 & 15.70 & 22.98 & 1.20 \\
\hline Nitrogen (Urea@31.25 kg N ha-1) & 14.98 & 11.41 & 5.69 & 2.18 & 19.28 & 9.82 & 14.76 & 24.58 & 1.27 \\
\hline Sulphur (Gypsum @20 kg S ha ${ }^{-1}$ ) & 15.12 & 10.45 & 5.36 & 2.20 & 18.01 & 10.20 & 14.88 & 25.09 & 1.39 \\
\hline $\begin{array}{l}\text { Nitrogen (Urea@ @ } 31.25 \mathrm{~kg} \mathrm{~N} \mathrm{ha}^{-1} \text { ) + } \\
\text { Sulphur (Gypsum @ } 20 \mathrm{~kg} \mathrm{~S} \mathrm{ha}^{-1} \text { ) }\end{array}$ & 16.56 & 8.62 & 5.65 & 2.18 & 16.46 & 13.33 & 14.49 & 21.49 & 1.31 \\
\hline Critical difference $(\mathrm{P} \leq 0.05)$ & 0.12 & 0.18 & 0.14 & NS & 0.31 & 0.16 & 0.19 & 0.42 & NS \\
\hline
\end{tabular}

NS- Not significant

Table 2. Effect of nitrogen and sulphur fertilization on relative composition (\%) of purified glycinin polypeptides in soybean seeds.

\begin{tabular}{|c|c|c|c|}
\hline Treatment & A1-A4 & Acidic & Basic \\
\hline Control & 13.04 & 4.09 & 12.76 \\
\hline Nitrogen (Urea@31.25 kg N ha ${ }^{-1}$ ) & 15.15 & 4.64 & 11.58 \\
\hline Sulphur (Gypsum @20kg S ha ${ }^{-1}$ ) & 15.73 & 4.62 & 11.80 \\
\hline $\begin{array}{l}\text { Nitrogen (Urea@31.25 kg N ha }{ }^{-1} \text { ) + } \\
\text { Sulphur (Gypsum @20 kg S ha }{ }^{-1} \text { ) }\end{array}$ & 11.69 & 6.91 & 11.03 \\
\hline Critical difference $(\mathrm{P} \leq 0.05)$ & 0.19 & 0.16 & 0.23 \\
\hline
\end{tabular}


Table 3. Effect of nitrogen and sulphur fertilization on relative composition (\%) of purified $\beta$-conglycinin polypeptides in soybean seeds.

\begin{tabular}{|c|c|c|c|}
\hline Treatment & $\alpha^{\prime}$ & $\alpha$ & $\beta$ \\
\hline Control & 8.00 & 6.69 & 9.45 \\
\hline Nitrogen (Urea@31.25 kg N ha ${ }^{-1}$ ) & 12.0 & 6.89 & 9.05 \\
\hline Sulphur (Gypsum @ 20 kg S ha ${ }^{-1}$ ) & 8.30 & 2.41 & 8.88 \\
\hline Nitrogen (Urea@31.25 kg N ha-1) + & 7.10 & 2.29 & 9.40 \\
\hline Sulphur (Gypsum@20kg S ha ${ }^{-1}$ ) & & & \\
\hline Critical difference $(\mathrm{P} \leq 0.05)$ & 0.11 & 0.13 & 0.20 \\
\hline
\end{tabular}

conglycinin storage proteins were similar in all the treatments (Fig. 1). The broad band (approximately 85 $\mathrm{kDa}$ ) at the top corresponded to the three unresolved lipoxygenase isoenzymes. Three subunits of 7S protein fraction, $\alpha^{\prime}, \alpha$ and $\beta$ with molecular weights of approximately 74, 65 and $45 \mathrm{kDa}$ were resolved on the gel, and $11 \mathrm{~S}$ protein fraction was separated into acidic and basic subunits. The groups of polypeptides near the molecular weight of about 35 and $20 \mathrm{kDa}$ were a major group of acidic and basic polypeptides, respectively.

For quantification of subunit fractions of $11 \mathrm{~S}$ and $7 \mathrm{~S}$ proteins, densitometric analysis of seed storage proteins separated by SDS-PAGE was carried out. The relative proportion of $\alpha^{\prime}, \alpha$ and $\beta$ subunits of $\beta$ conglycinin in control was 10.82, 6.09 and $2.18 \%$, respectively (Table 1). The application of $\mathrm{S}$ alone or in combination with $\mathrm{N}$ significantly decreased the amount of $\alpha^{\prime}$, and $\alpha$ subunits whereas the amount of $\beta$ subunit was unaltered by the same treatments when compared to control. Treatment of $\mathrm{N}$ alone significantly $(\mathrm{P} \leq 0.05)$ increased the relative proportion of $\alpha^{\prime}$ subunit and decreased $\alpha$ subunit quantity in comparison to control. The total content of $7 \mathrm{~S}$ in control was $19.10 \%$ which decreased significantly by the treatment of $\mathrm{S}$ alone or in combination with $\mathrm{N}$, and the maximum decrease was observed in the combined treatment of $\mathrm{N}$ and $\mathrm{S}(16.46 \%)$. There were non-significant variations in total $7 \mathrm{~S}$ proportion between control and $\mathrm{N}$ treatment. The relative proportion of acidic subunit of glycinin in control was $7.28 \%$ that increased significantly $(\mathrm{P} \leq 0.05)$ by the treatment of $\mathrm{N}, \mathrm{S}$ alone or in

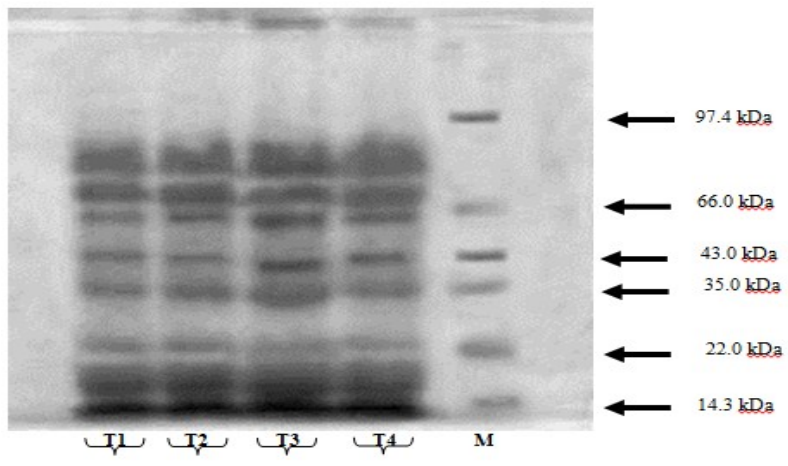

Fig.1. SDS-PAGE profile of storage protein accumulation in soybean seeds under influence of $N$ and $S$ supplementation. $T 1=$ Control (No fertilizer),T2=Urea@31.25 kg N ha ${ }^{1}, T 3=$ Gypsum @ $20 \mathrm{kgSha} a^{-1}$, T4=Urea@31.25 kg Nha ${ }^{-1}$ + Gypsum@20 kg Sha combination viz., $9.82 \%, 10.20 \%$ and $13.33 \%$, respectively. The total glycinin content also increased significantly by the treatment of $\mathrm{N}(24.58 \%)$ and S $(25.09 \%)$ alone in comparison to control $(22.98 \%)$. The $11 \mathrm{~S}: 7 \mathrm{~S}$ ratio increased by all the treatments as compared to control, thus improving the protein quality.

Glycinins and $\beta$-conglycinins were further fractionated, and the purified protein fractions were loaded on SDS-PAGE gels for the separation of their subunits. Separated subunits on the gels were further quantified by densitometric analysis. The groups of polypeptides near the molecular weight of approximately 45-66 kDa were A1-A4 polypeptides collectively; $35-40$ and 20$22 \mathrm{kDa}$ were a major group of acidic and basic subunits, respectively. The relative proportion of $\mathrm{A} 1-\mathrm{A} 4$, acidic and basic subunits of glycinin in control were $13.04,4.09$ and $12.76 \%$, respectively (Table 2 ). The treatment of $\mathrm{N}$ and $\mathrm{S}$ alone significantly increased the relative quantity of A1-A4 subunits as compared to control. The proportion of acidic subunits increased significantly by all the fertilizer treatments in comparison to control; the maximum increase was reported by the combined application of $\mathrm{N}$ and $\mathrm{S}$ that varied significantly from other treatments as well.

The relative proportions of subfractions of $\beta$ conglycinins in control were $8.0 \%\left(\alpha^{\prime}\right), 6.69 \%(\alpha)$ and $9.45 \%(\beta)$, respectively (Table 3$)$. The application of $\mathrm{N}$ alone significantly $(\mathrm{P} \leq 0.05)$ increased the quantity of $\alpha^{\prime}$, and $\alpha$ subunits whereas the treatment of $\mathrm{S}$ alone or combined with $\mathrm{N}$ significantly $(\mathrm{P} \leq 0.05)$ decreased the relative proportions of these subunits as compared to control. The relative percentage of $\beta$-subunit of $\beta$ conglycinins decreased significantly $(\mathrm{P} \leq 0.05)$ when recommended dose of $\mathrm{N}$ and $\mathrm{S}$ were applied alone but a non-significant decrease was observed with combined application of $\mathrm{S}$ and $\mathrm{N}$ in comparison to control. Soybean protein quality is largely determined by its subunit composition. This is especially true in case of $\beta$-subunit of $\beta$-conglycinin, a protein that is deficient in $\mathrm{S}$ containing amino acids, cysteine and methionine (Taski Hajdukovic et al., 2008). Eliminating or reducing the $\beta$-subunit of $\beta$-conglycinin and increasing $\mathrm{S}$ containing amino acids has been suggested as one method of improving the quality of soybean proteins (Krishnan et al., 2005). The level and composition of seed storage proteins is regulated by sulphur and nitrogen supplies (Tabe et al., 2002). In the present studies, a significant decrease in $\beta$-subunit of $\beta$-conglycinin 
and increase in the acidic subunits of glycinin after the gypsum application (Tables 1 and 3 ) depicts the role of $\mathrm{S}$ in improving soybean protein quality. $\mathrm{S}$ application has been reported to increase glycinin synthesis which contains high proportions of cysteine and methionine, in soybean (Krishnan et al., 2005; Granvogl et al., 2008). The application of glutathione to immature soybean cotyledons reduced the accumulation of the $\beta$ subunit of $\beta$-conglycinin and increased the accumulation of glycinin (Awazuhara et al., 2002). Further, Kim et al. (2014) demonstrated that ample supply of reduced sulphur during seed filling promotes soybean protein quality by reducing the accumulation of sulphur-poor $7 \mathrm{~S} \beta$-conglycinins. Likewise, providing an exogenous source of methionine to soybean plants results in 23 and $31 \%$ increase in methionine and cysteine content, respectively (Yi et al., 2010). This observation suggests if one could increase the concentration of cysteine/methionine in developing seeds, then it should be feasible to accumulate sulphur-rich heterologous proteins to a level sufficient to meet the nutritional requirement of livestock and poultry (Jez and Krishnan, 2009; Yi et al., 2010).

Nitrogen application increases grain protein concentration but decreases protein quality as it tends to increase the $\mathrm{S}$ poor $\beta$-subunit of $\beta$-conglycinin (Bennett et al., 2003) and lower the $S$ amino acid content of soybean by regulating the accumulation of Bowman-Birk protease inhibitor, a protein rich in cysteine (Krishnan et al., 2005). However, the recommended dose of $\mathrm{N}$ (Urea@31.25 kg N ha ${ }^{-1}$ ) employed in the current work did not increase the relative proportion of $\beta$ subunit of $\beta$-conglycinin. Moreover, it improved the protein quality by increasing the quantity of acidic subunits of glycinin when applied alone or in combination with S (Table 2). Earlier work from our laboratory showed that pre-planting nitrogen application @ 12.5 and $25 \mathrm{~kg} \mathrm{ha}^{-1}$ resulted in increased accumulation of acidic subunit of glycinin (sulphur rich) in soybean genotypes PK416 and SL831 (Kaur, 2009). On the other hand, in genotypes SL525, SL783 and SL869, although increased $\mathrm{N}$ application resulted in increased protein accumulation, but the quality decreased due to higher accumulation of $\beta$-subunit of $\beta$-conglycinin.

\section{Conclusion}

It can be concluded from the present study that application of $\mathrm{N}$ and $\mathrm{S}$ alone decreased the relative proportion of $\beta$-subunit of purified $\beta$-conglycinin fraction while the acidic polypeptides of glycinin fraction of globulin were increased in all the treatments and maximum increase was reported after the combined application of gypsum with the recommended dose of urea. $11 \mathrm{~S}: 7 \mathrm{~S}$ ratio was also improved by recommended $\mathrm{N}$ dose and S fertilizer application as gypsum @, $20 \mathrm{~kg} \mathrm{~S}$ $\mathrm{ha}^{-1}$ under agro-climatic conditions of Punjab that indicated improvement in protein quality.

\section{REFERENCES}

Adachi, M., Kanamori, J., Masuda, T., Yagasaki, K., Kitamura, K., Mikami, B. and Utsumi, S. (2003). Crystal structure of soybean $11 \mathrm{~S}$ globulin: glycinin A3B4 homohexamer. Proc Nat Acad Sci USA, 100: 7395-7400.

Arslanoglu, F., Aytac, S. and Oner, E.K. (2011). Effect of genotype and environment interaction on oil and protein content of soybean (Glycine $\max$ (L.) Merrill) seed. African J Biotechnol, 10(80): 18409-18417.

Awazuhara, M., Kim, H. and Hayashi, H. (2002). Composition of seed storage proteins changed by glutathione treatment of soybean. Biosci Biotechnol Biochem, 66: 1751-1754

Basha, S.M.M. and Beevers, L. (1975). The development of proteolytic activity and protein degradation during germination of Pisum sativum (L.). Planta, 124: 77-87.

Beilinson, V., Chen, Z., Shoemaker, R.C., Fischer, R.L., Goldberg, R.B. and Nielsen, N.C. (2002). Genomic organization of glycinin genes in soybean. Theor Appl Gen, 104: 1132-1140.

Bennett, J.O., Krishnan, A.H., Weibold, W.J. and Krishnan, H.B. (2003). Positional effect on protein and oil content and composition of soybeans. J Agric Food Chem, 51: $6882-6886$

Fehr, W.R., Hoeck, J.A., Johnson, S.L., Murphy, P.A., Nott, J.D., Padilla, G.I. and Welke, G.A. (2003). Genotype and environment influence on protein components of soybean. Crop Sci, 43: 511-514.

Granvogl, M., Wieser, H., Koehler, P., Von, T.S. and Schieberle, P. (2008). Influence of sulphur fertilization on the amounts of free amino acids in wheat. Correlation with baking properties as well as with 3aminoproprionamide and acrylamide generation during baking. J Agric Food Chem, 55: 4271-4277.

Jez J.M. and Krishnan, H.B. (2009). Sulphur assimilation and cysteine biosynthesis in soybean seeds: towards engineering sulphur amino acid content. Modification of seed composition to promote health and nutrition, ASACSSA-SSSA Publishing, Madison, pp 249-261.

Kaur, M. (2009). Influence of nitrogen application on various biochemical parameters of different soybean (Glycine $\max ($ L.) Merril) genotypes. M.Sc. Thesis, Punjab Agricultural University, Ludhiana.

Kim, W., Jez, J.M. and Krishnan, H.B. (2014). Effects of proteome rebalancing and sulphur nutrition on the accumulation of methionine rich $\delta$-zein in transgenic soybeans. Frontiers Plant Sci, 5: 1-12.

Kopriva, S. and Rennenberg, H. (2004). Control of sulphate assimilation and glutathione synthesis: interaction with $\mathrm{N}$ and C metabolism. J Exp Bot 55(404): 1831-1842.

Krishnan, H.B., Bennett, J.O., Kim, W., Krishnan, A.H. and Mawhinney, T.P. (2005). Nitrogen lowers the sulphur amino acid content of soybean (Glycine max [L.] Merr.) by regulating the accumulation of Bowman-Birk protease inhibitor. J Agric Food Chem, 53: 6347-6354.

Laemmli, U.K. (1970). Cleavage of structural protein during the assembly of the heads of bacteriophage T4. Nature, 227: $680-685$.

Lowry, O.H., Rosbrough, N.J., Farr, A.L. and Randall, R.J. (1951). Protein measurement with the folin phenol reagent. J Biol Chem, 193: 265-275.

Poysa, V., Woodrow, L. and Yu, K. (2006). Effect of soy 
protein subunit composition on tofu quality. Food Res Intern, 39: 309-317.

Siddiqui, M.H., Mohammad, F., Khan, M.N. and Khan, M.M.A. (2008). Cumulative effect of soil and foliar application of nitrogen, phosphorus and sulphur on growth, physico-biochemical parameters yield attributes and fatty acid composition in oil of erucic acid-free rapeseed-mustard genotypes. J Plant Nutr, 31: 12841298.

Tabe, L., Hagan, N. and Higgins, T.J.V. (2002). Plasticity of seed protein composition in response to nitrogen and sulphur availability. Curr Opin Plant Biol, 5: 212-217.

Taski Hajdukovic, K., Djordjevic, V., Vidic, M., Vujakovic, M., Milosevi, M. and Miladinovic, J. (2008). The main seed storage proteins among high-protein genotypes. Genetika, 40: 9-16.
Tea, I., Genter, T., Naulet, N., Marie, L.M. and Kleiber, D. (2007). Interaction between nitrogen and sulphur by foliar application and its effects on flour bread-making quality. J Agric Food Chem, 87: 2853-2859.

Thanh, V.H. and Shibasaki, K. (1978). Major proteins of soybean seeds. Subunit structure of $\beta$-conglycinin. $J$ Agric Food Chem, 26: 692-695.

Yaklich, R.W. (2001). $\beta$-conglycinin and glycinin in high protein soybean seeds. J Agric Food Chem, 49: 729-735.

Varier, A. and Dadlani, M. (1992). Effect of ageing on profiles of soluble protein of cotton and esterase isoenzymes of pearl millet seeds. Ind J Plant Physiol, 352: $145-57$.

Yi, H., Ravilious, G.E., Galant, A., Krishnan, H.B. and Jez, J.M. (2010). From sulphur to homoglutathione: thiol metabolism in soybean. Amino Acids, 39: 963-978. 